\title{
Concentration Level of Heavy Metals in Soil at Vegetables Areas in Kota Bharu, Kelantan, Malaysia
}

\author{
Haliza Abdul Rahman and Farah Adhila Zaim
}

\begin{abstract}
The study was focused on heavy metals which are copper $(\mathrm{Cu})$, zinc $(\mathrm{Zn})$ and lead $(\mathrm{Pb})$ that are known as the most toxic and poisonous to human health. The objectives of this research was to determine, analysis and compare the heavy metal concentration level in two study areas at Kg. Kubang Edang, Peringat and Kg. Tok Kambing, Sering, both are in Kota Bharu, Kelantan, Malaysia. The result obtained in the soil samples of $\mathrm{Kg}$. Kubang Edang shows that $\mathrm{Pb}$ concentration has highest concentration of heavy metals with $7.396 \mathrm{mg} / \mathrm{L}$ followed by $\mathrm{Zn}, 7.077 \mathrm{mg} / \mathrm{L}$ and $\mathrm{Cu}$ has the lowest concentration with $3.705 \mathrm{mg} / \mathrm{L}$. On the other hand, the result obtained in the soil samples of $\mathrm{Kg}$. Tok Kambing shows that $\mathrm{Pb}$ has the highest concentration with $11.304 \mathrm{mg} / \mathrm{L}$ followed by $\mathrm{Zn}$ with concentration level of $10.667 \mathrm{mg} / \mathrm{l}$ and $\mathrm{Cu}$ has the lowest concentration with $4.576 \mathrm{mg} / \mathrm{L}$. The result shows heavy metals concentration level in $\mathrm{Kg}$. Tok Kambing was higher as compared to Kg. Kubang Edang. Analyzing the data using parametric T-test shows that, there were significant differences of heavy metals concentration level in two study areas with p-value $<\mathbf{0 . 0 5}$.
\end{abstract}

Index Terms-Heavy metal, concentration, vegetable area, Kg. Kubang Edang, Kg. Tok Kambing.

\section{INTRODUCTION}

Soil is one of the important environmental components. Soil is important as it roles as a medium for plant growth where it can recycle the nutrient and resources needed by plant. Heavy metals may be added and present in the soil due to agricultural activities such as agricultural fertilizers and pesticides, soil amendments, organic fertilizers and in waste materials recycled to the soil.

Soils are the major sinks for heavy metals released into the environment by aforementioned anthropogenic activities and unlike organic contaminants which are oxidized to carbon (IV) oxide by microbial action, most metals do not undergo microbial or chemical degradation, and their total concentration in soils persists for a long time after their introduction [1]. Accumulation of heavy metal in the environment becomes a health hazard because of their persistence, bioaccumulation and toxicity to plants, animals and human beings.

Vegetables are exposed to the heavy metals contamination

Manuscript received December 18, 2014; revised February 4, 2015.

Haliza Abdul Rahman is with the Department of Environmental and Occupational Health, Faculty of Medicine and Health Sciences, Universiti Putra Malaysia, 43400 UPM Serdang, Selangor, Malaysia (e-mail: dr.haliza@upm.edu.my).

Farah Adhila Zaim was with Health Sciences (Environmental and Occupational Health), School of Health Sciences, Universiti Sains Malaysia, 16150 Kubang Kerian, Kelantan, Malaysia (e-mail: dila_acu90@yahoo.com). because one of the reason identified is the polluted agricultural soil has been used to cultivate the plants. Heavy metals that are attached with soil water and soil particles will be absorbed by plant roots and accumulated in vegetables [2]. As example, cuprum $(\mathrm{Cu})$, arsenic (As) and plumbum $(\mathrm{Pb})$ were accessible in agricultural soils in Australia and New Zealand as a result of long-lasting heavy use of pesticides [3]. Moreover, in the study of heavy metal content of agricultural soils in Mediterranean semiarid area: the Segura River Valley (Alicante, Spain) showed a sequence of heavy metals concentration in the agricultural soil which are $\mathrm{Fe}$ $(45,274)>\mathrm{Mn}>\mathrm{Zn}(57.8)>\mathrm{Cr} 928.3)>\mathrm{Ni}(23.7)>\mathrm{Cu}(21.6)>\mathrm{Pb}$ (19.6) $>\mathrm{Co}(7.9)>\mathrm{Cd}(0.38)$ [4]. Accumulation of heavy metal in crop plants becomes a great concern because above certain level of concentration, they have adverse effect to human health which causal to much type of diseases.

The accumulation of heavy metal in the soil crop system has been considered as one pathway to human exposed to the heavy metal. A lot of studies showed that increasing the heavy metals content in the soil increases the uptake by plants but, the solubility and availability of heavy metals ions are influenced by various factors such as soil $\mathrm{pH}$, physical and chemical soil properties, clay content and magnesium oxide concentration [5].

\section{A. Study Area}

The agriculture still is the main base for Malaysia's economy although the industrial sector has contributed much too economic development. In Kelantan, agricultural is one of the resident's main activities especially for those stay in rural areas. This study was focused agricultural site in rural areas around Kota Bharu, the capital of Kelantan State. Kota Bharu districts cover an area of 409 kilometers $(\mathrm{km})$ per square. There have 14 districts, 131 parishes and 601 villages under the administration of Kota Bharu. The 14 districts are Pendek, Kubang Kerian, Kemumim, Peringat, Badang, Banggu, Panji, Salor, Limbat, Ketereh, Kadok, Sering, Beta and Kota [6].

Two study areas have been selected which are Kg. Kubang Edang, Peringat and Kg. Tok Kambing, Sering. Both study areas are located in Kota Bharu. The distance between $\mathrm{Kg}$. Kubang Edang and Kg. Tok Kambing are $18 \mathrm{~km}$.

\section{B. Research Objective}

To study the concentration levels of heavy metal in soil at vegetables areas in between $\mathrm{Kg}$. Kubang Edang and Kg. Tok Kambing.

\section{Agricultural Activities and Heavy Metal Threats}

About $15 \%$ of daily food intake in Malaysian population which is comprise from vegetables. Most consumers now are demanding for a better quality of vegetables which are 
healthy, succulent and fresh looking vegetables without any visible rashes or holes caused by pests or diseases. Therefore to satisfy the demand, the farmers need to tackle pests and diseases problems by any methods for examples the usage of pesticides which are cheaper and give immediate results. But unconsciously the application of pesticides created another problem associated with pesticides abuse related to toxic residues that are hazardous to health and environment [7].

Activities such as agricultural clearly have spread heavy metal to the environment and tend to accumulate in certain tissue in the human body and will become toxic even in low doses. In intensively farmed areas, agricultural developments use large amounts of pesticides and organic and inorganic fertilizer inputs. Coca, groundnut, mustard and rice had elevated concentrations of heavy metals (especially $\mathrm{Cu}$ and $\mathrm{Zn}$ ) assessed when compared to other plants (cabbage, oil palm, aubergine, lady's fingers). This may be contributed by the widespread use of $\mathrm{Cu}$ and $\mathrm{Zn}$ pesticides on these crops. A survey also showed that heavy metal concentration in surface horizon and in edible parts of vegetables increased over time [8].

As plant requires necessary nutrients such as nitrogen, phosphorus and potassium, they also accumulate metals such as $\mathrm{Pb}$ and $\mathrm{Cd}$ [5]. It was suggested that $\mathrm{Cd}$ would be the most mobile element in the soil and more available to crop, with great risk of moving into the food chain [8].

Heavy metals contamination in vegetables can be considered as a gateway to heavy metals poisoning in food and ultimately have an impact on human. There have a wide range of pesticides compound including insecticides, fungicides, herbicides, rodenticides, molluscicides, nematicides, plant growth regulators and others. The major types of pesticides are the organochlorine pesticides, which are known for high toxicity, persistence in the environment and their bioaccumulation in the food chain [9].

An earlier study on the assessment of contamination of agricultural soils and crops in Peninsular Malaysia showed that some soils already contain elevated values of $\mathrm{Cd}$ and $\mathrm{Zn}$ and those cabbages may show high value of $\mathrm{Cu}$. The Malaysian soil investigative levels for heavy metals was also established and proposed to be the $95^{\text {th }}$ percentile [10].
Recently, residues in traded food commodities are also monitored by many countries and there are increasing incidences of trade in agricultural commodities being prohibited on the basis of contaminant concentrations [11]. As example, from 1993-1996, a total of 15 types of vegetables from Sabah, Malaysia were officially banned for export to Brunei and Sarawak due to excessive pesticide residues at the rate of 31 to $75 \%$ of the sample [7].

It has been stated that different types of vegetables have different abilities to accumulate the metals plus plants are known to respond to the amounts of readily mobile type of metals in soils [5]. In 1996, seven pesticides (acephate, chlopyriphos, chlopyriphos-methyl, methamidophos, iprodione, procymidone and chlorothalonil) and two groups of pesticides (benomyl group and maneb group were analyzed in apples, tomatoes, lettuces, strawberries and grapes). The results found that $5.2 \%$ of the samples contain residues and $0.31 \%$ had higher residues and the lettuce crop have the highest value of mancozeb. While in 1999, there have four commodities such as cauliflower, pepper, wheat grains and melon were analyzed for the same 20 pesticides and from here the results are the residues of methamidophos are highest $(8.7 \%)$, followed by the maneb group $(1.1 \%)$, thiabendazole 90.57), acephate $(0.41 \%)$ and the benomyl group $(0.35 \%)$. Besides that, methamidophos was exceeded most often in peppers and melons (18.7\% and 3.7\% respectively) [12].

Others than pesticides, fertilizers also have negative effects on agricultural soil because its might contain heavy metals. Application of certain phosphatic fertilizers in advertently adds $\mathrm{Cd}$ and other potentially toxic elements to the soul including $\mathrm{F}, \mathrm{Hg}$ and $\mathrm{Pb}$. The addition of large quantities of fertilizers to soils in intensive farming system to provide adequate nitrogen $(\mathrm{N})$, phosphorus $(\mathrm{P})$ and potassium $(\mathrm{K})$ but after continued fertilizers application may significantly increase their trace heavy metals in soil [1].

In the study of heavy metals in soils and crops in Southeast Asia, Peninsular Malaysia have shown that an increasing value of $\mathrm{As}, \mathrm{Cu}$ and $\mathrm{Zn}$ in agricultural soil resulted from the addition of phosphatic fertilizers [11]. Furthermore, Table I shows the study on concentration of heavy metal in fertilizers and pesticides used among farmer in the paddy areas [13].

TABLE I: The Concentration of Heavy Metals (MG/KG) In SElected Fertilizers And Pesticides

\begin{tabular}{|c|c|c|c|c|c|c|c|}
\hline Fertilizer and pesticides & \multicolumn{7}{|c|}{ Heavy metals (mg/kg) } \\
\hline & $\mathrm{Pb}$ & $\mathrm{Cd}$ & $\mathrm{Cr}$ & $\mathrm{Cu}$ & $\mathrm{Zn}$ & $\mathrm{Fe}$ & $\mathrm{Mn}$ \\
\hline Fenthion & 0.19 & 0.01 & 0.01 & $\mathrm{ND}$ & 0.09 & 1.46 & ND \\
\hline Carbaryl & 0.17 & 0.01 & ND & ND & 0.25 & 0.58 & ND \\
\hline Urea & 0.15 & 0.01 & ND & ND & 0.14 & 0.36 & ND \\
\hline NPK 13:13:21 & 0.22 & 0.01 & 0.08 & ND & 0.41 & 8.71 & 0.73 \\
\hline NPK 12:12:17 & 0.23 & 0.02 & 0.56 & ND & 0.95 & 10.15 & 0.36 \\
\hline
\end{tabular}

Source: [13]

From health perspective, ingestion of vegetables grown in soils contaminated with heavy metals poses a possible risk to human health and wildlife. [5] Exposure to heavy metals is normally chronic (exposure over a longer period of time), due to food chain transfer. Due to their cumulative behavior and toxicity, heavy metals are potentially hazardous not only to crop production, but also to human health through food consumption, groundwater contamination and accumulation in food crops. [13] For example, Hg pollution will spread over and being absorbs into the soil and will enter hydrology cycles, from here the mercury start to change to methylmercury from methylation process through bacteria exist in water and soil. Then, those elements will absorb by other live organism thus cause bioaccumulation in their body.

Among the major effects of using pesticides are endocrine disorders, reproductive damage and development, neurotoxic, increase in morbidity and so on. Pesticides is termed as endocrine disruptors which elicit their adverse effects by mimicking natural hormones in the body and linked to human health effects such as immune suppression, hormone 
disruption, diminished intelligence, reproductive abnormalities and cancer [12].

The excessive intake of contaminated food from metals will lead to a number of diseases such as kidney damage and/or skeletal damage, and both metals acts as human carcinogen in the body [14]. Dietary intake was also identified as a major source of $\mathrm{Cd}$ exposure apart from the tobacco smoke. Seafood, leafy vegetables, rice, grains and legumes may contain high levels of $\mathrm{Cd}$ in comparison [15]. Toxicity of $\mathrm{Cd}$ is more dangerous to human because it could result painful bone demineralization where $\mathrm{Cd}$ could replace $\mathrm{Ca}$ in bones [16].

\section{METHODOLOGY}

The soil was collect from two rural agriculture areas in two villages around Kota Bharu. Two villages were chosen as study areas because both agricultural areas planting the same types of crop which is cucumber and have same width of areas which is a hectare (ha). The soil was analyzed using atomic Absorption Spectrophotometer (AAS) to identify the heavy metal concentration level in both agricultural soils. The heavy metals chosen for analyses are $\mathrm{Cu}, \mathrm{Pb}$ and $\mathrm{Zn}$. The results were interpreted into Statistical Package for the Social Science (SPSS) by comparing heavy metals concentration level on the both villages.

\section{A. Research Design}

This study done by collecting the soil samples from the study location and were brought back to the laboratory for further analysis. At the study location, the samples were taken at three various points. Around three samples are taken at each point selected. In this experiment, the experiment divided into three phases which is sampling and pre-treatment stage, sample digestion or extraction stage using Acid Digestion Method and analysis of the sample by using AAS in order to determine the concentration of heavy metal in soil. [17]

\section{B. Sample Size}

The soil samples were taken using a soil corer with the depth of 0 to $20 \mathrm{~cm}$ [18]. For this study, random sampling is applied by randomly choose three points which each points is located at the starting, middle and end of the area of 1 ha $(10 \mathrm{~m} \times 10 \mathrm{~m})$ where the three points selected are at the same gap distance of $4.5 \mathrm{~m}$. The starting point is starts at $1 \mathrm{~m}$ followed by middle point at $5.5 \mathrm{~m}$ and at the end point of $10 \mathrm{~m}$. at each point selected, another three sub-points are taken at one line of the crop limits with the $7.5 \mathrm{~m}$ length. The gap distances of three subs-points are at $1 \mathrm{~m}, 4.25 \mathrm{~m}$ and $7.5 \mathrm{~m}$. the sub-samples were homogenized into one composite sample per points for further analysis.

\section{Sample Preparation}

Three samples were collected at each point in the selected area. The soil samples taken by using a soil corer, from the depth $0-20 \mathrm{~cm}$ from the surface and were placed in individual plastic bag and transported to the laboratory. The plastic bags were labelled with name, sampling date, location and soil depth.

The samples were air-dry to remove excess moistures. The samples then mashed up using pestle and mortar and grinder in order to obtain a uniform state of the samples and passed through a $2 \mathrm{~mm}$ sieve of aluminium foil. Any gravel, stones and plants fragment found in the samples were removed to obtain a homogenous sample. The method is adapted from Rossi and Kuwata [19].

The soil samples taken need to undergo a few process or stages before the sample can be prepared using acid digestion method. The soils are dried in the drying oven at the temperature of $50^{\circ} \mathrm{C}$ for three days and grinded to pass through a $2 \mathrm{~mm}$ soil sieve to get a homogenized particle size. Then, the soil samples were weighed using analytical balance and ready for acid digestion extraction method before analyzed using AAS. $60 \%$ of concentrated $\mathrm{HCI}$ and $\mathrm{HNO}_{3}$ are mixed into soil sample to be heated on the hotplate. Finally, each soil sample solution was filtered through qualitative filter paper into a $50 \mathrm{ml}$ volumetric flask. For analysis using AAS, the solution in the $50 \mathrm{ml}$ volumetric flask were diluted with deionized water to the mark on the volumetric flask.

Determination of $\mathrm{Cu}, \mathrm{Pb}$ and $\mathrm{Zn}$ concentration in acid digestion extraction of soil samples is using AAS. For analyzing using AAS, standard solutions were prepared by serial dilution. Stock standard solution can be prepared directly from reagent grade chemicals. Finally, the sample solutions were put to the AAS to obtain reading.

\section{RESULTS}

The mean concentrations of $\mathrm{Cu}, \mathrm{Pb}$ and $\mathrm{Zn}$ for every sampling period are shown in Table II. Table III shows a comparison between all heavy metal in Kg. Kubang Edang. $\mathrm{Cu}$ has the lowest mean concentration which is $3.705 \mathrm{mg} / \mathrm{L}$ with range between $2.160 \mathrm{mg} / \mathrm{L}$ to $5.910 \mathrm{mg} / \mathrm{L}$ compare with another two heavy metals which are $\mathrm{Pb}$ and $\mathrm{Zn}$. $\mathrm{Pb}$ has the highest mean concentration which is $7.396 \mathrm{mg} / \mathrm{L}$ with the range between $5.570 \mathrm{mg} / \mathrm{L}$ to $9.650 \mathrm{mg} / \mathrm{L}$.

TABLE II: MEAN CONCENTRATIONS FOR EVERY SAMPLING (A) KG. KUBANG ENDANG

\begin{tabular}{|c|c|c|c|}
\hline & $\mathrm{Cu}$ & $\mathrm{Pb}$ & $\mathrm{Zn}$ \\
\hline $1^{\text {st }}$ & 2.554 & 7.044 & 6.636 \\
\hline $2^{\text {nd }}$ & 4.056 & 7.241 & 6.267 \\
\hline $3^{\text {rd }}$ & 5.037 & 7.516 & 6.656 \\
\hline $4^{\text {th }}$ & 3.763 & 6.344 & 7.717 \\
\hline $5^{\text {th }}$ & 3.392 & 7.094 & 7.377 \\
\hline $6^{\text {th }}$ & 3.507 & 9.136 & 7.771 \\
\hline mean & 3.718 & 7.396 & 7.055 \\
\hline
\end{tabular}

(B) KG. TOK KAMBING

\begin{tabular}{|l|l|l|l|}
\hline \multicolumn{1}{|c|}{ (B) KG. TOK KAMBING } & $\mathrm{Cu}$ & $\mathrm{Pb}$ & $\mathrm{Zn}$ \\
\hline $1^{\text {st }}$ & 3.465 & 10.762 & 9.461 \\
\hline $2^{\text {nd }}$ & 4.212 & 12.439 & 9.891 \\
\hline $3^{\text {rd }}$ & 5.085 & 11.952 & 10.592 \\
\hline $4^{\text {th }}$ & 6.037 & 9.505 & 11.735 \\
\hline $5^{\text {th }}$ & 3.914 & 10.333 & 11.221 \\
\hline $6^{\text {th }}$ & 4.745 & 12.829 & 11.416 \\
\hline mean & 4.576 & 11.303 & 10.719 \\
\hline
\end{tabular}

While in $\mathrm{kg}$. Tok Kambing, $\mathrm{Cu}$ has the lowest mean concentration which is $4.576 \mathrm{mg} / \mathrm{L}$ with the range of 3.154 $\mathrm{mg} / \mathrm{L}$ to $6.570 \mathrm{mg} / \mathrm{L}$. Thus, $\mathrm{Pb}$ has the highest concentration which is $11.304 \mathrm{mg} / \mathrm{l}$ with the range of $8.270 \mathrm{mg} / \mathrm{l}$ to 13.609 $\mathrm{mg} / \mathrm{L}$ (Table IV). 
TABLE III: THE MEAN CONCENTRATION, STANDARD DEVIATION AND Range OF THE HEAvy METAL IN KG. Kubang EDANG

\begin{tabular}{|c|c|c|c|c|}
\hline $\begin{array}{c}\text { Heavy } \\
\text { metal }\end{array}$ & $\begin{array}{l}\text { No. of } \\
\text { sample }\end{array}$ & $\begin{array}{l}\text { Concentration } \\
\text { mean }(\mathrm{mg} / \mathrm{L})\end{array}$ & $\begin{array}{l}\text { Std. Dev. } \\
(\mathrm{SD}) \\
(\mathrm{mg} / \mathrm{L})\end{array}$ & $\begin{array}{l}\text { Range } \\
(\mathrm{min}-\mathrm{max}) \\
(\mathrm{mg} / \mathrm{L})\end{array}$ \\
\hline $\mathrm{Cu}$ & 54 & 3.705 & 0.889 & $2.160-5.910$ \\
\hline $\mathrm{Pb}$ & 54 & 7.396 & 0.998 & $5.570-9.650$ \\
\hline $\mathrm{Zn}$ & 54 & 7.077 & 1.054 & $5.124-10.600$ \\
\hline
\end{tabular}

TABLE IV: THE MEAN CONCENTRATION, STANDARD DEVIATION AND RANGE OF THE HEAVY METAL IN KG. TOK KaMBING

\begin{tabular}{|r|r|c|c|c|}
\hline $\begin{array}{l}\text { Heavy } \\
\text { metal }\end{array}$ & $\begin{array}{c}\text { No. of } \\
\text { sample }\end{array}$ & $\begin{array}{l}\text { Concentration } \\
\text { mean }(\mathrm{mg} / \mathrm{L})\end{array}$ & $\begin{array}{l}\text { Std. Dev. } \\
(\mathrm{SD}) \\
(\mathrm{mg} / \mathrm{L})\end{array}$ & $\begin{array}{l}\text { Range (min-max) } \\
(\mathrm{mg} / \mathrm{L})\end{array}$ \\
\hline $\mathrm{Cu}$ & 54 & 4.576 & 1.005 & $3.154-6.570$ \\
\hline $\mathrm{Pb}$ & 54 & 11.304 & 1.278 & $8.270-13.609$ \\
\hline $\mathrm{Zn}$ & 54 & 10.667 & 0.934 & $1.685-12.515$ \\
\hline
\end{tabular}

\section{A. Independent T-Test}

Parametric independent T-test has been employed to identify the comparison of mean concentration of heavy metal between two sampling locations which are Kg. Kubang Edang and Kg. Tok Kambing. Statistical test shows that there has significant difference between two villages either in $\mathrm{Cu}, \mathrm{Pb}$ and $\mathrm{Zn}$ with significant value ( $\mathrm{p}$-value $<0.05$ ). The statistical data for heavy metal that are $\mathrm{Cu}, \mathrm{Pb}$ and $\mathrm{Zn}$ are shown in Table V.

TABLE V: THE StATISTICAL DATA FOR PARAMETRIC INDEPENDENT T-TEST IN TWO VILLAGES

\begin{tabular}{|cccccc|c|}
\hline $\begin{array}{c}\text { Heavy } \\
\text { metal }\end{array}$ & $\begin{array}{c}\text { Group } \\
\text { Kg. } \\
\text { Kubang } \\
\text { Edang } \\
\text { Mean(SD) }\end{array}$ & $\begin{array}{c}\text { Kg. Tok } \\
\text { Kambing } \\
\text { Mean(SD) }\end{array}$ & p-value \\
& $\begin{array}{c}\text { Mean diff. } \\
\text { (95) }\end{array}$ & $\begin{array}{c}\text { t-stat } \\
(\mathrm{df})\end{array}$ & \\
\hline $\mathrm{Cu}$ & 3.705 & 4.576 & 0.871 & 4.771 & $p<0.05$ \\
\hline & $(0.889)$ & $(1.005)$ & $\begin{array}{c}(0.509, \\
1.233)\end{array}$ & $(106)$ & \\
\hline $\mathrm{Pb}$ & 7.068 & 10.806 & 3.738 & 19.860 & $p<0.05$ \\
\hline & $(0.675)$ & $(1.207)$ & $\begin{array}{c}(3.365, \\
4.111)\end{array}$ & $(106)$ & \\
\hline $\mathrm{Zn}$ & 7.077 & 10.667 & 3.589 & 18.732 & $p<0.05$ \\
\hline & $(1.054)$ & $(0.934)$ & $\begin{array}{c}(3.210, \\
3.969)\end{array}$ & $(106)$ & \\
\hline
\end{tabular}

TABLE VI: The StAndard/Limits For HeAvy Metal in SoIL Proposed BY OTHER AGENCIES

\begin{tabular}{|c|c|c|c|}
\hline \multirow[t]{2}{*}{ Limits } & \multicolumn{3}{|c|}{ Heavy metal (mg/L) } \\
\hline & $\mathrm{Cu}$ & $\mathrm{Pb}$ & $\mathrm{Zn}$ \\
\hline Pte-Mbc [20] & 100 & 300 & 250 \\
\hline Italian Limits [18] & 120 & 100 & 150 \\
\hline $\begin{array}{l}\text { Dutch Intervention } \\
\text { Value }\end{array}$ & 190 & 530 & 720 \\
\hline $\begin{array}{l}\text { Standard regulatory } \\
\text { limits [21] }\end{array}$ & 30 & 20 & 90 \\
\hline $\begin{array}{l}\text { Threshold limit value } \\
\text { [22] }\end{array}$ & 75 & 100 & 200 \\
\hline Kg. Kubang Edang & 3.705 & 7.068 & 7.077 \\
\hline Kg. Tok Kambing & 4.576 & 10.806 & 10.667 \\
\hline
\end{tabular}

The result obtained from the study in both villages was below the limits or standard proposed by various agencies. A study of comparison of concentration of heavy metal in soil was showed in Table VI.

From the observation, in Kg. Kubang Edang, the farm is located in the village near with untouched forest, but there are a few houses were built near the farm which is the farmer's house. In $5 \mathrm{~m}$ before arrive at the farm, there have a few lots of paddy areas. Those houses were connected with a small tar road for villager's transportation. Within the $5 \mathrm{~m}$ radius of the farm, most of the activities done by villagers are involving agricultural activities such as planting paddy and vegetables (cabbage, cucumber, eggplant) and raising animals such as cattle, cow and goat. No industrial activities are seen around this area. Therefore, it can be concluded that, the agricultural soil in $\mathrm{Kg}$. Kubang Edang were not disturbed by any others industrial activities and there is low possibility of any pollutant from industrial activities to contaminate the soil in this area.

Compare to $\mathrm{Kg}$. Tok Kambing, this area reasonable to have the heavy metal concentration level higher than the concentration in the Kg. Kubang Edang because the highway constructed for road transportation contaminates nearby agricultural soil. According to Han et al. [23], $\mathrm{Pb}, \mathrm{Cu}$ and $\mathrm{Zn}$ were the main pollutant comes from the highway constructed for road transportation. However, the heavy metal concentration level in $\mathrm{Kg}$. Tok Kambing is still below the limits proposed for soil.

\section{DISCUSSION}

Pest and diseases problems are the major factors militating against increased vegetable production in the tropics thus bring heavy losses through yield reduction, lowered quality of produce, increased costs of production and harvests [24]. The pests usually found are insect's pests, vertebrates, molluscs, weeds, nematodes and pathogenic diseases such as fungi, bacteria and viruses. A pest for example weeds is known to be a competitor with the crops in order searching for water, light and nutrients. If this problem cannot be managed properly it can cause yield losses of up to $40-60 \%$.

Therefore, to control all these problems, farmers tend to used chemical such as pesticides on their crops. Although heavy metal concentration level in both villages are below the standards proposed by various agencies, but still have to prevent those level under the standards by introducing a better practices so that the farmers can continues using the good practices for a sustainable agriculture. The pesticides will present various negative impacts on the crops then to the health effects of the consumers.

In Malaysia, there have many types of pesticide has been sold, but, all of the must registered by the Board of Pesticides to enable the distributions, imported, manufactured, sold and used are legally. The registration process has to be renewed every 5 years. This ensures the pesticides used in Malaysia are safe to use, does not have high residues or residues and thus not pollute the environment if used properly and prudently in accordance with good agricultural Practices (GAP).

The farmers also been advised only to use pesticides when the percentage of damage area are more than $10 \%$ problems on the crops. If the crops were damage below than $10 \%$, the crops cannot be treat with any pesticides to prevent the crops absorbed the chemical produced by the pesticides such as heavy metal elements. Furthermore, farmers also not advised to treat the crops when it produces fruit buds because the buds can absorb the heavy metal contained in pesticide during the 
growth of crops. When the crops were attacked by the fruit flies, the pesticides were used only once in a week not continuously from seedling to fruiting stage.

To prevent the plants uptake the heavy metals and accumulate in the plants root or other parts of plant from the pesticides, there are guidelines shown in Table VII which to prohibit farmers to harvest the crops after using a few type of pesticides.

TABLE VII: THE GUIDELINE OF PERIOD OF HARVESTING PROHIBITION AFTER USING PESTICIDES

\begin{tabular}{|c|c|}
\hline Pesticides & $\begin{array}{c}\text { Period of harvesting } \\
\text { prohibition (days) }\end{array}$ \\
\hline Dimethoate & 14 \\
\hline Prophenphos & 3 \\
\hline Bendiacarb & 7 \\
\hline Malathion & 3 \\
\hline Carbaryl & 3 \\
\hline Phenthion & 3 \\
\hline Carbendazine & 14 \\
\hline Tridemorph & 3 \\
\hline Benomyl & 3 \\
\hline Maneb & 7 \\
\hline Captan & 3 \\
\hline Mancozeb & \\
\hline
\end{tabular}

Source: [25]

Farmers are also adopting rotational cultivation techniques. Farmers can grow plants and vegetables in rotation with different vegetables types to keep and maintain soil fertility. For example, when plant the mustard, the land can be planted with beans or corn plant because different types of plants require different nutrients and substances. In this way, farmers are not only able to maintain the soil fertility but also save costs by not spreading fertilizer for the next crop. Lastly, farmers also can practice hydroponics method in order to reduce of fertilizer and its concentration level in the soil.

In the study areas, based on observation, the farmers have implemented biological control. Biological controls are using the pest's natural enemies that can affect the growth, reproduction pests and control the population back into balance. In Kampung Tok Kambing as example, some of the farmers use dragonflies as biological control to overcome the fruit flies that attack the fruit of crops.

The farmers also can manage the crop pests by physical and mechanical control which there use the equipment, structures, heat or energy work which can act directly on the pests. For example, in Kampung Kubang Edang, the farmer has applied the insect's traps such as lights and stickers. The farmers have employed the flies' sticker which acts to trap the flies due to glue on the sticker.

\section{CONCLUSION}

It's been proved that, the soil from agricultural activities content of some contaminants such as heavy metals. The introduction of pesticides and chemical fertilizers become one of those factors influenced the arising of contaminant in the soil at agricultural areas.

The finding shows that by conducting sampling of soil on selected vegetables areas produced the selected heavy metals concentration levels which are $\mathrm{Cu}, \mathrm{Pb}$ and $\mathrm{Zn}$. The T-test shows there is significance difference of heavy metals concentration level between two study areas.the findings shows that the heavy metals concentration level in $\mathrm{Kg}$.Tok Kambing is higher compare to the $\mathrm{Kg}$. Kubang Edang.

The sustainable and goo agricultural activities employed by the farmers in two sampling location is identified to be the best sources or reasons the heavy metal concentration level are below the standard propose by various agencies.

\section{REFERENCES}

[1] R. A. Wuana and F. E. Okieimen, "Heavy metals in contaminated soils: A review of sources, chemistry, risks and best available strategies for remediation," International Scholarly Research Network, p. 20, 2011.

[2] E. R. Aweng, M. Karimah, and O. Suhaimi, "Heavy metals concentration of irrigation water, soils and fruit vegetables in Kota Bharu Area, Kelantan, Malaysia," Journal of Applied Sciences in Environmental Sanitation, vol. 6, no. 4, pp. 463-470, 2011.

[3] D. W. Yap, J. Adrezrian, B. S. Ismail, and R. Ahmad-Mahir, "The uptake of heavy metals by paddy plants (oryza sativa) in Kota Marudu, Sabah, Malaysia," American-Eurasian Journal Agricultural \& Environmental Science, vol. 6, no. 1, pp. 16-19, 2009.

[4] C. Mico, M. Peris, J. Sanchez, and L. Recatala, "Heavy metal content of agricultural soils in Mediterranean semiarid area: the Segura river valley (Alicante, Spain)," Spanish Journal of Agricultural Research, vol. 4, no. 4, pp. 363-372, 2006.

[5] B. S. Ismail, Racun Makhluk Perosak, Universiti Kebangsaan, Malaysia Publisher: Bangi, 1988

[6] Department of Town \& Country Planning of Kelantan State, Laporan Pemeriksaan Rancangan Struktur Negeri Kelantan 2003-2020, 2005

[7] J. Jinius, A. B. Alinah, R. J. Jaimi, and P. K. Phua, "Management of pesticide use of vegetable production: Role of Department of Agriculture Sabah," in Proc. $6^{\text {th }}$ SITE Research Seminar, Department of Agricultural, Sabah, 2001.

[8] Y. Luo, L. Wu., L. Lin, C. Han, and L. Zhu. (2009). Heavy metal contamination and remediation in Asian agricultural land. Chinese Academy of Sciences. [Online]. Available: http://niaes.affrc.go.jp/marco/marco2009/english/program/S1_LuoY M.pdf

[9] A. G. Jiries, F. M. Al-Nasir, and F. Beese, "Pesticide and heavy metals residue in wastewater, soils and plants in wastewater disposal site near Al-Lajoun Valley, Karak/Jordan," Water, Air and Soil Pollution, vol 133, pp. 97-107, 2000

[10] S. Zauyah, B. Juliana, R. Noor Hafizah, C. I. Fauziah, and A. B Rosenani, "Concentration and speciation of heavy metals in some cultivated and uncultivated ultisols and inseptisols in Peninsular Malaysia," in Proc. $3^{\text {rd }}$ Australian New Zealand Soils Conference, 2004.

[11] A. B. Zarcinas, I. Fauziah, M. J. Mclaughin, and G. Cozens, "Heavy metals in soils and crops in Southeast Asia," Environmental Geochemistry and Health, vol. 26, pp. 343-357, 2003.

[12] M. W. Aktar, D. Sengupta, and A. Chowdhury, "Impact of pesticides use in agriculture: Their benefits and hazards," Interdisciplinary Toxicology 2, vol. 2, no. 1, pp. 1-12, 2009.

[13] J. Habibah, P. T. Lee, J. Khairiah, M. A. Razali, A. Fouzi, and B. S Ismail, "Speciation of heavy metals in paddy soils from selected areas in Kedah and Penang, Malaysia," African Journal of Biotechnology, vol. 10, no. 62, pp. 13505-13513, 2011.

[14] A. K. Salama and A. R. Radwan, "Heavy metals $(\mathrm{Cd}, \mathrm{Pb})$ and trace elements $(\mathrm{Cu} . \mathrm{Zn})$ contents in some foodstuffs from Egptian market, Emir," Journal Agricultural Sciences, vol. 17, no. 1, pp. 34-42, 2005.

[15] A. Hasmah, "Heavy metal and human health," in Environmental and Society Health, H. A. Rahman and R. Suppian, Eds. Universiti Utara Malaysia Publisher: Sintok, 2011, pp. 113-145.

[16] M. Zia-ur-Rehman, A. Ghafur, M. Sabir, N. S. Asif, and R. A. Hamaad, "Extractants for the assessment of phyto-available cadmium of rice grown in cadmium contaminated soils," Journal of Agricultural Sciences, vol. 45, no. 1, pp. 11-17, 2008.

[17] A. Kushairi, "Determination of heavy metal concentration in top surface and sub-surface soil around Ulu Tualang Closed Landfill, Temerloh, Pahang," Thesis of Bachelor of Degree, Faculty of Chemical and Natural Resources Engineering, University Malaysia Pahang, unpublished, 2010.

[18] M. Poggio, E. Hepperle, F. A. Marsan et al., "Metals pollutions and human bioaccessibility of topsoils in Grugliasco, Italy," Environmental Pollution, vol. 157, pp. 680-689, 2008. 
[19] Rossi and Kuwata, Chemistry 222, Experiment 3: Determination of lead in Soil by Atomic Spectroscopy, Spring 2008.

[20] B. Wei and L. Yang, "A review of heavy metal contaminations in urban soils, urban roads dusts and agricultural soils from China," Microchemical Journal, vol. 94, pp. 99-107, 2010.

[21] O. V. Akpoveta, S. A. Osakwe, B. E. Okoh, and B. O. Otuya, "Physicochemical characteristics and levels of some heavy metals in soils around metal scrap dumps in some part of Delta State, Nigeria," Journal of Application Science Environmental Management, vol. 14, no. 40 , pp. $57-60,2010$.

[22] P. Sipos and T. Poka, "Threshold limit values for heavy metals in soils in the function of spatial and temporal variation of geochemical factors," Laboratory for Geochemical Research, Hungarian Academy of Sciences, 2002.

[23] D. C. Han, X. K. Zhang, V. V. S. Tomar, Q. Li., D. Z. Wen, and W. Liang, "Effects of heavy metal pollutions of highway origin soil nematode guilds in North Shenyang, China," Journal of Environmental Sciences, vol. 21, no. 2, pp. 193-198, 2008.

[24] F. O. Olasantan, E. A. Makinde, and A. W. Salau. (1997). Vegetable crops production (HRT 501). [Online]. Available: http://www.unaab.edu.ng/attachments/482_HRT\%20501.pdf

[25] Department of Agriculture Peninsula Malaysia, Cucumber Technology Package, 1st ed. JP/BK 03-02/12/97/1200R, 1997.

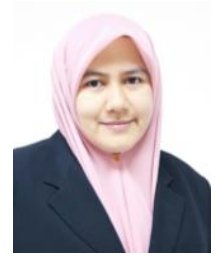

Haliza Abdul Rahman is an associate professor at the Environmental and Occupational Health Department, Faculty of Medical and Health Sciences, Universiti Putra Malaysia, Malaysia. Her research specialized in environment and development, environmental management, public awareness in environmental issues and current environmental issues. Currently, she is doing a research on participation and involvement of public in environmental issues, environmental management and social aspects of climate change issues.

She graduated from University of Malaya, Malaysia in 1998. Then she pursues her study in National University of Malaysia in 1999 for master degree in environmental management. In 2005, she got her PhD degree in environment and development also from National University of Malaysia.

Dr. Haliza published more than 35 journals, 75 papers in proceedings, 50 chapters in book and 12 books. She started her academia in university since 2005. From 2005 to 2013, she was a lecturer in environmental and occupational health programme, School of Health Sciences, Universiti Sains Malaysia before moved to Universiti Putra Malaysia in 2013.

Farah Adhila Zaim is a bachelor ex-student of Health Sciences (Environmental and Occupational Health), School of Health Sciences, Universiti Sains Malaysia, 16150 Kubang Kerian, Kelantan, Malaysia Presently, she is working with private company in the field of environment. 